\title{
Nurturing Intellectual Warriors: A Nationalistic Approach
}

\author{
Swami Veereshananda Saraswathi \\ President \\ Ramakrishna - Vivekananda Ashrama \\ Ramakrishna Nagar, Tumakuru - 572102 \\ Karnataka, India
}

Tel: 91-94482-68280. E-mail: rkvat@yahoo.com

Received: November 23, 2020

doi:10.5296/jss.v6i1.18131
Accepted: December 30, $2020 \quad$ Published: December 31, 2020

URL: https://doi.org/10.5296/jss.v6i1.18131

\begin{abstract}
Man enjoys his intellect more than an animal enjoys its senses. Thirst for knowledge is inherent in man and no one likes to be ignorant. Knowledge alone can remove ignorance. Sir Julian Huxley, renowned biologist defines the new goal of evolution at the human level as refinement of intellect which gives fulfilment. It is easy to train and purify our impure intellect, if we know the different aspects and functions of Buddhi. The pure intellect has many characteristics such as - Alertness, Discrimination, Determination, Subtlety, Steadiness, Maturity, Vastness, Simplicity, Sharpness, and Positivity. The intense and purer the intellect (Buddhi), the greater the perfection attained. That country is great which can produce more intellectual people in different fields. Intellectual strength (buddhibalam) alone can play a vital role in a nation's progress. We need to process our psychic energy into - creative, constructive and making for happiness and all-round welfare. This kind of development is what makes education a blessing to society. That is the goal of India in our present condition when we are developing into a constructive, developed nation.
\end{abstract}

Keywords: Intellect, Knowledge, Education, Concentration, Evolution, Refinement, Psychic energy, Nation

\section{Introduction}

Man enjoys his intellect more than an animal enjoys its senses. "What do we mean by intelligence? Reactive power...The intellect is the determining faculty and decides upon what is brought to it.....Intellect is necessary, for without it we fall into crude errors and make all sorts of mistakes. Intellect checks these; but beyond that, do not try to build anything upon it," says Swami Vivekananda. Thirst for knowledge is inherent in man and no one likes to be ignorant. Knowledge alone can remove ignorance. A beautiful verse in Chanakya Niti (17:17) says: 


\section{Jnanam naraanamadhiko visheshah| \\ Jnanena hinah pashubih samaanaah\|}

'What distinguishes a man from an animal is his capacity to acquire knowledge. Without knowledge men are equal to animals.' There is a popular saying:

\section{Swadesho pujyate raja vidwan sarvatra pujyate|}

'The king is honoured only in his kingdom whereas a learned person is honoured everywhere. Hence the Taittiriya Upanishad says (1.19):

\section{Swadhyayapravachanabhyam na pramaditavyam}

'Do not be careless about learning and teaching.'

Intellectual conviction is possible only through right understanding. We praise Mahaveer Hanuman as the most distinguished among intellectuals (Buddhimatam Varishthah) because of his sharp intellect. When Indrajit tied Sri Rama and Lakshmana with the Nagapasha, Hanuman, who was capable of finding a solution for any problem, descended from the sky with Garuda, Lord Vishnu's vehicle and enemy of snakes. A quick solution and a quick action is a sign of sharp intellect.

\section{Significance of Intellect}

The goal of evolution at the human stage is not organic satisfaction, numerical increase, or organic survival. Sir Julian Huxley, renowned biologist defines the new goal of evolution at the human level as refinement of intellect which gives fulfilment.

The intense and purer the intellect (Buddhi), the greater the perfection attained. That country is great which can produce more intellectual people in different fields. Intellectual strength (buddhi balam) alone can play a vital role in a nation's progress.

\section{Nurturing Intelligence - Education}

Intellect is superior to the mind and the senses. In a hunger for food, the hunger is satisfied by taking food. In a hunger for knowledge, we satisfy it by education, by study, by thinking. Our education has been more instruction than education, more conveying of static information than stimulation of thinking, more stuffing the brain than training the mind.

Since independence, the Nation has been trying to unify and channelize all the various insights on the subject of education into constructive policies and programmes. These programmes contain within them the basic ingredient of what Swami Vivekananda called man-making education. That basic ingredient is the emphasis on work, labour of the hand in association with labour of the intellect; such a combination will produce intelligent, socially efficient individuals, unlike the usual academic intellectual education, which turns out only individuals with information stocked in their brain, but without the capacity for practical expression.

The object of the ideal system of education, then, should not merely be the advancement of theoretical knowledge but also the advancement of life, development of the highest powers and capacities, and unfolding of the noblest potentialities of the individual. He must be enabled at the same time to apply intelligently to his own life all the ideas that he has learnt and gathered and thus promote his growth-physically, intellectually, morally and spiritually. 
It is a dire necessity today to orient our education to what Vivekananda calls Man - Making_and Nation Building Purposes in the context of the new national strength and self-confidence. What we need today is to capture the intellectual and moral energy, to take full advantage of the favourable modern world conditions and the efficient technology of the modern age, and to affect a double efficiency in our people through our educational process, namely, thought and personality-efficiency within and work and productive-efficiency without. This double-efficiency is the essence of a man-making education.

True education must help the youth not only to develop physical vitality and sharpen their intelligence, but also to capture the heroic spirit, to ignite what India calls the Bhagiratha spark, in them, by developing and training their 'Will' to welcome every opportunity to face hardships and struggles and to utilize their psycho-physical organism to render service to their fellowmen.

\section{Potential of Intelligence}

Buddhi is extremely subtle, and, when it is properly trained, it develops a high penetrating power. Any energy can be made capable of deep penetration by giving proper training. Take radiation; you give it a training, high frequency training; then it becomes highly penetrating as an X-ray, though by itself, it was a very flimsy radiation.

All effective mental training, says Vedanta, is training in concentration; it is the development of a capacity for penetration, the penetration through the darkness of ignorance into the light of knowledge. Referring to this penetrative power of the trained mind, Swami Vivekananda says, "How has all the knowledge in the world been gained but by the concentration of the powers of the mind? The world is ready to give up its secrets if we only know how to knock, how to give it the necessary blow; the strength and of the blow come through concentration. There is no limit to the power of the human mind. The more concentrated it is, the more power is brought to bear on one point; that is the secret." By training the buddhi in dealing with subtle, more subtle and still more subtle realities, and the buddhi finally gets the capacity to realize the subtlest reality, the Truth. Suksma buddhi is capable of realizing the subtle, and sthula buddhi is capable of realizing only the gross. 'Suksmadarsibhih', 'is by those who have trained themselves to perceive subtle and subtler truths.' Such people are called 'Suksmadarsis'. One becomes a suksma darsi because of his or her single-pointed mind.

Buddhi is pure reason, as we call it in the modern language, but it is the purest of the psychic energy that you have. 'Psychic energies' mean all the energies in you. You go on training them, making it a little better; then it becomes the mind; making it still better, it becomes the buddhi. From the same energy, namely, that psychic force, the buddhi must be developed. Through education you develop that buddhi which can discriminate between the real and the unreal, and penetrate into the heart of things. That is called buddhi. 'Buddhau saranam anviccha', 'take refuge in buddhi' and develop buddhi in you.

\section{Cerebral System - Organic Instrument of Buddhi}

The cerebral system is the organic instrument of that buddhi. The cerebral system is the latest development of the brain in human beings. It is meant to control and regulate the entire human organism other than the organism's automatic functions. By understanding this, and trying to practise this a little, anybody can develop this buddhi within oneself as an instrument of achieving the goal of evolution at the human stage. It is manufactured out of the psycho-physical energy system within everybody. We only purify that energy, refine it; then it becomes buddhi. 


\section{Refinement of Psychic Energies}

All high character is based upon the refining of psychic energies. Raw psychic energy gives you crude character. We have refineries in India now, we take crude oil and refine that oil, and out of that refinery we get beautiful petroleum products including fine scents. Similarly, take crude experience, refine it, and then, send out beautiful products of character- love, compassion, peace, efficiency of work, dedication. Today, in the concept and practice of education all over the world, there is very little of this refining of experience.

\section{Different Aspects and Functions of Intellect}

It is easy to train and purify our impure intellect, if we know the different aspects and functions of Buddhi. The pure intellect has many characteristics such as - Alertness, Discrimination, Determination, Subtlety, Steadiness, Maturity, Vastness, Simplicity, Sharpness, and Positivity.

Keen observation and thoughtful actions are the signs of an alert intellect. Discriminative intellect helps us to take right decisions, but it is the function of the determinative intellect to put them into practice. If we study the lives of great luminaries, we find that they were men of tremendous will power and firm determination.

Reason or knowledge can give only facts. But to convert all that knowledge into action, one needs dhrti, determination; that 'will' must be oriented to the welfare of society as a whole. Gandhiji had that type of 'will'. When he visited the Viceroy, Lord Erwin in Simla, and the talks went on the whole night up to 3 am in the morning and at 30 ' clock he slept. But exactly at $4 \mathrm{am}$, his scheduled time, he got up and started his routine. Here one can see the action of dhrti. The whole of that dhrti is illumined to give a luminous dhrti, ever engaged in the good of the nation. Our India will become a heaven when our people will have this type of character that is expounded in the Gita.

Great things in life can be achieved only through a subtle intellect. With the help of gross intellect we see only the surface, but a subtle intellect can penetrate into the mysteries of the universe. Great scientists, poets, musicians could attain success only through a penetrating subtle intellect. The finer the quality of the energy, the greater is its power of impact and the wider its scope and range of action. This is the explanation of the enormous energies manifested by the world's spiritual giants like Buddha and Jesus, Ramakrishna and Vivekananda.

We may possess numerous excellences, but unless we develop a steady mind we will not benefit much. A steady intellect alone can help us to continue our struggle in spite of difficulties and obstacles in our path. Such a mind alone can lead to intellectual maturity.

A person with mature intellect cannot remain satisfied with his own comforts, but shows concern for others and always tries to help them and this in turn, helps him to expand his own heart and intellect. When a person lets go his individuality and identifies himself with the whole existence, he is called a man of vast intellect.

Simplicity is one of the most important characteristics of pure intellect. The thoughts, words and actions of a person with simple intellect are always in conformity with one another.

Presence of mind, right understanding, sharp memory, the ability to find solutions to problems are a few characteristics of a sharp intellect. Sharp memory is one of the signs of sharp intellect and those who possess it are called Shruthidhara. To attain success in life and to reach the desired goal one must have a 
positive attitude. Faith in oneself and in God, courage, strength and fearlessness are the characteristics of a positive intellect.(Aastikya buddhih) Studying Swami Vivekananda will help us develop a positive attitude.

\section{Refined Psychic Energy - Blessing to Society}

We need to process our psychic energy into - creative, constructive and making for the happiness and all-round welfare. This kind of development is what makes education a blessing to society. That is the goal of India in our present condition when we are developing into a constructive, developed nation. From the age of five onwards, this development must come into the life of every child through occasional oriental guidance. Little by little this development must take place. This kind of training of the 'will' is the work we have before us in education and in religion.

Our problems like poverty and backwardness cannot be overcome without stress on work, efficient work, and teamwork; these are all great demands on our national character today. When we become good workers, producing goods and services, we shall solve the problems of mass poverty in India. All the people well fed, well educated, and well housed, what a beautiful development it will be, so productive efficiency is a profound message for all of us in developing countries especially for India.

\section{Conclusion}

Buddhi is a unique instrument for directing human life and for achieving human destiny. Patanjali suggested a most effective method to cultivate pure intellect. He says (2.33):

\section{Vitarkavaadane pratipaksha bhavanam}

'Evil thoughts should be immediately replaced by contrary thoughts.'

The moment we get disturbed by evil thoughts, we should immediately start pondering over the words of the scriptures and of great people, which will help us to overcome negative thoughts.

God has given us intellect and also the free will to exercise it. It is left to us as to put it to best use. Sri Ramakrishna warned: 'Be a devotee, but don't be a fool.' Swami Vivekananda supported this view when he said, 'I would rather see every one of you rank atheists than superstitious fools'.

Bhagavad Gita says, "Buddhinashaathpranashyati" - From destruction of intelligence man perishes. Sri Krishna also says that Buddhi yoga is one of the paths for self-realization. When the Lord is pleased with His devotees He bestows His grace in the form of pure intellect. The path of knowledge is a tough path, and therefore this emphasis on a clear and sharp mind. We have to be intelligent and strong in our convictions.

It is a challenge for us to expand and refine our intellect. Evolution of intellect (Buddhi) within the human system is the best type of education that we can have. A strong, steady and humanly oriented intellect brings blessings to millions of people.

\section{References}

Complete works of Swami Vivekananda. (1989). (1st subsidized ed.). Advaita Ashrama. Mayavati.

Swami Ranganathananda. (2000). Universal Message of Bhagavad Gita (1st ed.). Advaita Ashrama. Mayavati.

Swami Ranganathananda. (2008). Vivekachudamani (1st ed.). Advaita Ashrama. Mayavati. 


\section{Macrothink}

Journal of Safety Studies

ISSN 2377-3219

2020, Vol. 6, No. 1

Swami Srikantananda.(2001). Intelligent Way to Yoga. Sri Ramakrishna Math. Mylapore. Chennai.

\section{Copyright Disclaimer}

Copyright for this article is retained by the author(s), with first publication rights granted to the journal.

This is an open-access article distributed under the terms and conditions of the Creative Commons Attribution license (http://creativecommons.org/licenses/by/4.0/) 